\title{
EFEKTIVITAS SOSIALISASI PENCEGAHAN KEBAKARAN HUTAN DAN LAHAN PADA MASYARAKAT DI DESA SUNGAI BULUH KECAMATAN BUNUT KABUPATEN PELALAWAN RIAU
}

\author{
Nurdin $^{1}$, Muhammad Badri' ${ }^{2}$, Dewi Sukartik ${ }^{3}$ \\ ${ }^{1,2,3}$ Program Studi Ilmu Komunikasi FDK UIN Suska Riau \\ Email: nurdin1966@gmail.com
}

Diterima : 3 Januari 2018

Disetujui : 15 Februari 2018

Diterbitkan : 28 Februari 2018

\begin{abstract}
Abstrak
Sosialisasi pencegahan kebakaran hutan dan lahan di Desa Sungai Buluh Kecamatan Bunut Kabupaten Pelalawan dinilai belum efektif. Hal ini terbukti bahwa masyarakat di Desa Sungai Buluh belum memahami secara detail tentang aturan membakar hutan dan lahan. Masyarakat hanya paham kalau membakar hutan dan lahan bisa masuk penjara. Penelitian tentang efektivitas sosialisasi pencegahan Kebakaran Hutan dan Lahan (Karhutla) adalah untuk mengetahui pengaruh kegiatan sosialisasi yang dilakukan pemerintah, swasta dan LSM terhadap pemahaman, motivasi dan tindakan masyarakat dalam proses pencegahan Karhutla di Desa Sungai Buluh Kecamatan Bunut Kabupaten Pelalawan. Kajian ini menggunakan pendekatan positivisme dan konstruktivisme, dikuatkan dengan teori sosialisasi.Teknik pengumpulan data menggunakan angket, FGD, dan wawancara. Hasil penelitian menemukan sosialisasi yang dilaksanakan pemerintah, swasta dan LSM kepada masyarakat di Desa Sungai Buluh Kecamatan Bunut belum berjalan dengan efektif. Namun, kegiatan sosialisasi mempengaruhi pengetahuan dan tindakan masyarakat secara signifikan pada kegiatan pencegahan Karhutla, akan tetapi kegiatan sosialisasi tidak mempengaruhi motivasi masyarakat secara signifikan. Hal ini disebabkan kegiatan sosialisasi hanya dihadiri perwakilan aparatur desa tidak langsung kepada masyarakat secara keseluruhan.
\end{abstract}

Kata Kunci: Sosialisasi, pemahaman, motivasi, dan tindakan pencegahan

\section{PENDAHULUAN}

Karhutla di Indonesia pada saat ini dapat dipandang sebagai peristiwa bencana regional dan global. Hal ini disebabkan karena dampak dari kebakaran hutan sudah menjalar ke negara-negara tetangga dan gas-gas hasil pembakaran yang diemisikan ke atmosfer (seperti $\mathrm{CO}_{2}$ ) menimbulkan pemanasan global. Karhutla di Indonesia tidak hanya terjadi di lahan kering tetapi juga di lahan basah seperti lahan dan hutan gambut, terutama pada musim kemarau, dimana lahan basah tersebut mengalami kekeringan. Pembukaan lahan gambut berskala besar dengan membuat saluran atau parit telah menambah risiko terjadinya kebakaran di saat musim kemarau (Ginting, 2008).

Data yang dirilis FIRMS Web Fire Mapper (NASA) 2015 memberikan gambaran secara komulatif selama periode Januari 2014-Januari 2015 sebaran titik api di Indonesia berdasarkan data satelit NASA khusus di Pulau Sumatera paling banyak terdapat di Riau (NASA, 2015). Melihat pola perkembangan titik panas tersebut, ada kecenderungan pada musim kemarau panjang Karhutla semakin sering terjadi. Hal ini disebabkan masyarakat atau perusahaan membuka lahan dengan cara membakar. Sebab cara tersebut dinilai lebih 
mudah dan murah. Pola pikir demikian sudah tertanam di masyarakat, sehingga akan terus dilakukan setiap musim kemarau.

Bencana Kebakaran Hutan dan Lahan (Karhutla) akhir-akhir ini sudah semakin mengganggu, baik ditinjau dari sudut pandang sosial maupun ekonomi. Pencemaran lingkungan tidak dapat dihindarkan, bahkan sudah mempengaruhi berbagai hal termasuk hubungan politik dengan negara tetangga (Sahat dan Supena, 2007). Karhutla seolah-olah menjadi suatu hal yang biasa dan terus berulang tiap tahun, 2014 merupakan kasus Karhutla terbesar selama 17 tahun terakhir, yaitu sejak 1997. Karhutla datang lebih awal dari tahuntahun sebelumnya. Karhutla 2013 terjadi Juni-Agustus sementara itu 2014 terjadi Februari. Karhutla 2014 sudah masuk dalam kejadian luar biasa dan menetapkan status tanggap darurat dengan jumlah penderita Infeksi Saluran Pernapasan Akut (ISPA) mencapai 48.390 orang (PPE Sumatera, 2014).

Provinsi Riau yang terletak pada bagian pesisir timur Pulau Sumatra didominasi oleh hamparan gambut yang sangat luas yaitu 3.867.413 $\mathrm{H}^{2}$ atau sekitar 60,08\% dari luas gambut yang ada di pulau Sumatera, sehingga Provinsi Riau merupakan salah satu provinsi rawan bencana Karhutla. Indikator masih terus terjadinya Karhutla, pada setiap musim kemarau terjadi peningkatan jumlah titik api (hot spot). Akibatnya setiap tahun saat kemarau selalu dilanda bencana asap akibat Karhutla. Bahkan ada kecenderungan mengalami peningkatan dari tahun ke tahun. Pada 2011 terdapat 6.644 titik api. Jumlah tersebut bertambah sekitar 25 persen pada tahun 2012 menjadi 8.107 titik api. Kenaikan hampir 50 persen terjadi pada 2013 menjadi 15.112. Kebakaran di Provinsi Riau mencapai puncaknya pada 2014 dengan 21 ribuan lebih titik api (Tempo, 13 Desember 2014).

Kondisi yang terus berulang tersebut hingga kini terus berupaya dan mencari strategi penyelesaian yang efektif. Pemerintah Pusat maupun Pemerintah Daerah sudah berupaya dalam bentuk sosialisasi pencegahan dalam berbagai bentuk kegiatan. Akan tetapi belum memberikan hasil yang optimal dalam menciptakan pemahaman yang optimal bagi masyarakat yang bersentuhan langsung dengan lahan dan hutan. Sosialisasi yang dilaksanakan oleh Dinas Kehutanan, Badan Konservasi Sumber Daya Alam (BKSDA), Badan Lingkungan Hidup (BLH) dan Pusat Pengelolaan Ekoregion (PPE), serta binaan perusahaan-perusahaan swasta yang beroperasi di daerah rawan Karhutla, dan Badan Nasional Penanggulangan Bencana (BNPB) Provinsi Riau telah mengupayakan berbagai sosialisasi dalam pencegahan kebakaran hutan dan lahan.

Sosialisasi yang ditujukan kepada masyarakat agar mereka mempunyai pemahaman, motivasi dan kemudian melakukan tindakan terhadap kegiatan pencegahan karhutla. Namun tidak semua warga masyarakat mengerti dan menjalankan fungsinya dengan baik sebagai upaya pencegahan karhutla. Banyak warga masyarakat yang hanya berorientasi proyek semata, berorientasi jangka pendek, dan tidak memahami dengan baik kegiatan sosialisasi yang sampaikan kepada mereka. Padahal idealnya pembangunan berbasis masyarakat perlu melibatkan partisipasi masyarakat secara penuh mulai proses perencanaan, pelaksanaan, hingga evaluasi kegiatan. Dengan demikian masyarakat dapat terlibat aktif dan menjadi bagian dari program penanggulangan karhutla.

Berdasarkan hasil analisis data sekunder serta wawancara dengan fasilitator dari Mitra Insani dan pendamping masyarakat dari Pusat Pengelola Ekoregion Sumatera (PPE) Kementerian Lingkungan Hidup, diperoleh informasi bahwa sosialisasi yang intensif telah dijalankan dengan berbagai program dan berbagai sumber informasi Pemerintah Pusat, Daerah, Perusahaan dan LSM terutama sekali bagi masyarakat di Kecamatan Bunut Kabupaten Pelalawan Riau. Untuk itu harus dilakukan upaya khusus memastikan pemahaman, motivasi, tindakan dan keikutsertaan perwakilan orang-orang secara seimbang 
dalam program bantuan, termasuk kelompok rentan dan kelompok terpinggirkan dalam proses penanggulangan kebakaran hutan dan lahan.

Pendekatan sosialisasi terhadap penanggulangan bencana berbasis masyarakat menempatkan masyarakat sebagai aktor utama. Masyarakat yang berada di daerah rawan bencana hendaknya diposisikan sebagai subjek yang aktif dengan berbagai kemampuan dan kapasitasnya. Mereka mempunyai potensi berupa pengetahuan, keterampilan dan motivasi yang tinggi yang dapat dimanfaatkan untuk mengantisipasi dan melakukan penanganan bila terjadi bencana (Sudibyakto et al, 2012).

Adapun yang menjadi tujuan penelitian adalah mengetahui pengaruh kegiatan sosialisasi terhadap pemahaman, motivasi dan tindakan masyarakat dalam proses pencegahan Karhutla di Kecamatan Bunut Kabupaten Pelalawan.

\section{KERANGKA TEORITIS Komunikasi}

Harold D. Lasswell (dalam Arni Muhammad, 2005) mengatakan bahwa "komunikasi adalah siapa, mengatakan apa, dalam media apa, dan kepada siapa, dan apa efeknya (who say what, in ehich medium to whom what effect). Komunikasi merupakan proses penyampaian pesan dari komunikator kepada komunikan melalui media dengan menimbulkan efek.

Berdasarkan penjelasan Lasswell tersebut, dapat kita ketahui bahwa komunikasi adalah proses penyampaian pesan oleh komunikator kepada komunikan melalui media yang menimbulkan efek tertentu. Komunikasi tidak hanya menyampaikan dan menerima pesan. Namun jauh lebih dari itu, dimana terjadi pemahaman, perubahan sikap, pandangan, maupun perilaku komunikan terkait dengan pesan yang dikomunikasikan dan disosialisasikan.

Menurut Fiske (2012) terdapat dua mazhab utama didalam ilmu komunikasi. Pertama, kelompok yang melihat komunikasi sebagai transmisi pesan. Kelompok ini fokus dengan bagaimana pengirim dan penerima, mengirimkan dan menerima pesan. Kelompok ini juga sangat memperhatikan efisiensi dan akurasi. Pandangan ini melihat komunikasi sebagai suatu proses dimana seseorang mempengaruhi perilaku dan cara berpikir orang lain. Kedua, melihat komunikasi sebagai produksi dan pertukaran makna. Kelompok ini fokus dengan bagaimana pesan, atau teks, berinteraksi dengan manusia dalam rangka untuk memproduksi makna; artinya, pandangan ini sangat memperhatikan peran teks dalam budaya kita.

Pearson et al. (2011) mendefinisikan komunikasi sebagai proses menggunakan pesan untuk menghasilkan makna. Dimana komponen komunikasi meliputi: (a) Orang, yaitu mereka yang terlibat dalam proses komunikasi memiliki dua peran, baik sebagai sumber dan penerima pesan; (b) Pesan, adalah bentuk verbal dan non verbal ide, pikiran, atau perasaan bahwa satu orang (sumber) ingin berkomunikasi dengan orang lain atau sekelompok orang (penerima); (c) Saluran atau media, adalah sarana penyampaian pesan dari sumber ke penerima pesan; (d) Umpan balik, adalah respon penerima baik verbal dan nonverbal untuk pesan yang disampaikan sumber; (e) Kode, adalah susunan sistematis simbol yang digunakan untuk membuat makna dalam pikiran orang lain atau orang-orang; (f) Encoding dan decoding, komunikasi melibatkan penggunaan kode karena proses komunikasi dapat dilihat sebagai salah satu encoding dan decoding. Encoding didefinisikan sebagai proses menerjemahkan ide atau pemikiran ke kode. Decoding adalah proses untuk menempatkan berarti bahwa ide atau pemikiran; (g) Kebisingan, adalah setiap gangguan pada proses encoding dan decoding yang mengurangi kejelasan pesan.

Terdapat tiga pemahaman mengenai komunikasi, yakni komunikasi sebagai tindakan satu arah, komunikasi sebagai interaksi, dan komunikasi sebagai transaksi (Mulyana 2009):

1. Komunikasi sebagai tindakan satu arah. Komunikasi yang mengisyaratkan penyampaian pesan searah dari seseorang (atau lembaga) kepada seseorang 
(sekelompok orang lain), baik secara langsung (tatap muka) ataupun melalui media, seperti surat(selebaran), surat kabar, majalah, radio, atau televisi.

2. Komunikasi sebagai interaksi. Pandangan komunikasi sebagai interaksi menyetarakan komunikasi dengan proses sebab-akibat atau aksi-reaksi,yang arahnya bergantian. Komunikasi sebagai interaksi dipandang sedikit lebih dinamis daripada komunikasi sebagai tindakan satu arah.Salah satu unsur yang dapat ditambahkan dalam konsepkedua ini adalah umpan-balik (feed back).

3. Komunikasi sebagai transaksi. Dalam komunikasi transaksional,komunikasi dianggap telah berlangsung bila seseorang telah menafsirkan perilakuorang lain, baik perilaku verbal ataupun perilaku nonverbalnya. Pendekatan transaksional menyarankan bahwa semua unsur dalam proses komunikasi saling berhubungan.

Menurut Beebe et. al. (2010) komunikasi disebut efektif jika dapat memenuhi tiga kriteria:

1. Pesan yang disampaikan dipahami. Salah satu tujuan dasar komunikasi adalah membangun pemanhaman bersama atas pesan antara komunikator dan komunikan.

2. Pesan yang disampaikan dapat mencapai efek yang diinginkan. Mengingat komunikasi selalu bersifat intensional, komunikasi yang efektif harus dapat mencapai tujuan yang diinginkan.

3. Pesan yang disampaikan harus sesuai dengan etika komunikasi.Pesan yang memenuhi kedua kriteria di atas tapi disampaikan dengan cara yang tidak sesuai dengan etika komunikasi maka tidak dapat dikategorikan sebagai komunikasi yang efektif dan berhasil.

Komunikasi efektif harus direncanakan dengan memperhatikan situasi, waktu, tempat, dan pendengarnya. Untuk menciptakan komunikasi yang efektif ada beberapa kemampuan yang harus dimiliki oleh khalayak yaitu bertanya, melihat dan mendengar (Arredondo, 2007). Untuk membantu komunikasi dapat efektif, ada beberapa ketentuan untuk memudahkannya. Hal tersebut merupakan persyaratan dasar dalam berkomunikasi efektif (Rumanti, 2005), yaitu:

a. Kemampuan mengamati dan menganalisis persoalan,

b. Kemampuan menarik perhatian,

c. Kemampuan mempengaruhi pendapat,

d. Kemampuan menjalin hubungan dan suasana saling mempercayai.

\section{Sosialisasi}

Sosialisasi adalah sebuah proses penanaman atau transfer kebiasaan atau nilai dan aturan dari satu generasi ke generasi lainnya dalam sebuah kelompok atau masyarakat. Karena dalam proses sosialisasi diajarkan peran-peran yang harus dijalankan oleh individu, maka sosialisasi adalah sebagai teori mengenai peranan (role theory). Sosialisasi pada dasarnya adalah penyebarluasan informasi (program, kebijakan, peraturan) dari satu pihak (pemilik program, kebijakan, peraturan) kepada pihak-pihak lain (aparat, masyarakat yang terkena program, dan masyarakat umum). Isi informasi yang disebarluaskan bermacammacam tergantung pada tujuan program.

Kegiatan sosialisasi sebagai proses komunikasi, sangat erat kaitannya dengan disiplin ilmu komunikasi. Komunikasi pada dasarnya merupakan gambaran seseorang tentang stimulasi dalam pikiran orang lain atas kesadaran, pemahaman, dan perasaan akan pentingnya peristiwa, perasaan, fakta, opini, atau situasi (Santoso, 2010). Selain itu komunikasi diantara manusia adalah seni mentransmisi informasi, ide, dan sikap dari satu orang ke orang yang lain (Santoso, 2010). 
Dalam kajian ini dikemukakan bagaimana efektivitas sosialisasi kebakaran hutan dan lahan terhadap masyarakat, yang dilaksanakan oleh berbagai pihak yang berkepentingan terhadap kebakaran hutan dan lahan. Meskipun disadari bahwa tidak hanya institusi yang berkepentingan yang menjalankan fungsi sosialisasi terhadap masyarakat, akan tetapi sosialisasi dengan berbagai cara telah dijalankan Pemerintah Pusat dan Daerah, LSM, dan Pihak Swasta karena mereka menyampaikan pesan bersifat terbuka dan dapat menjangkau masyarakat.

Tanggung jawab sosialisasi dibebankan kepada seseorang atau lembaga tertentu, seperti orangtua, sekolah, kelompok, badan pemerintah, instusi swasta, LSM dan media massa. Orangtua terutama ibu dan media massa adalah lingkungan yang paling awal dijumpai seorang anak-anak dalam hidupnya (Liebes, 1992). Sosialisasi dilakukan dengan sengaja, untuk mencapai suatu tujuan. Hal inilah yang akan menjadi tumpuan dalam kajian ini. Akan tetapi, kadang-kadang terjadi sosialisasi yang tidak disengaja. Dan sosialisasi yang tidak disengaja, tidak dapat diperkirakan akibat yang ditimbulkannya.

Sama halnya dengan proses komunikasi, sosialisasi juga dianggap efektif apabila memenuhi beberapa persyaratan sebagaimana digambarkan oleh Rumanti (2005) yaitu masyarakat mempunyai (1) kemampuan mengamati dan menganalisis persoalan; (ii) kemampuan menarik perhatian; (iii) kemampuan mempengaruhi pendapat; dan (iv) kemampuan menjalin hubungan dan suasana saling mempercayai.

\section{Pemahaman Terhadap Bahaya Karhutla}

Pemahaman berarti mengerti, menguasai benar. Kamus umum bahasa Indonesia "pemahaman" berarti hal, hasil kerja dari memahami atau sesuatu hal yang kita pahami dan kita mengerti dengan benar. Menurut W.J.S Poerwodarminto (2003), pemahaman berasal dari kata "Paham" yang artinya mengerti benar tentang sesuatu hal. Sedangkan pemahaman adalah proses, perbuatan, cara memahami sesuatu.

Suharsimi Arikunto (1995) menyatakan bahwa pemahaman (comprehension) adalah kemampuan seorang mempertahankan, membedakan, menduga (estimates), menerangkan, memperluas, menyimpulkan, menggeneralisasikan, memberikan contoh, menuliskan kembali, dan memperkirakan. Dengan demikian dapat dimaknai bahwa pemahaman adalah suatu kemampuan seseorang dalam mengartikan, menafsirkan, menerjemahkan, atau menyatakan sesuatu dengan caranya sendiri tentang pengetahuan yang pernah diterimanya. Dan belajar adalah upaya memperoleh pemahaman. Dan seseorang dikatakan mengerti terhadap suatu konsep apabila ia dapat menjelaskan kembali dan menarik kesimpulan terhadap konsep tersebut. Pemahaman adalah suatu proses memberi makna terhadap pesan yang diterima sesorang dalam proses sosialisasi terhadap suatu isu yang disampaikan dengan sengaja dengan penuh pertimbangan untuk mencapai suatu tujuan tertentu.

Menurut Anderson et al. (2001), pemahaman terdiri dari tujuh jenis, yaitu:

1. Interpreting (interpretasi) terjadi ketika masyarakat mampu mengkonversi informasi dari satu representasi ke representasi yang lain. Interpretasi meliputi konversi kata-kata ke dalam kata-kata, gambar ke dalam kata-kata, dan sebagainya.

2. Exemplifying (pemberian contoh) terjadi ketika masyarakat mampu memberikan contoh spesifik atau contoh dari konsep umum atau prinsip. Exemplifying meliputi menemukan ciri-ciri dari konsep umum atau prinsip (misalnya, segitiga sama kaki harus mempunyai dua sisi sama panjang), dan menggunakan ciri-ciri tersebut untuk memilih atau mengkostruk contoh yang lebih spesifik (misalnya, mampu menentukan nama dari tiga buah segitiga yang disajikan adalah segitiga sama kaki). Nama lainnya adalah illustrating dan instantiating. 
3. Classifying (klasifikasi) terjadi ketika masyarakat mengenal bahwa sesuatu (contoh atau kejadian tertentu) termasuk kategori tertentu (misal konsep atau prinsip). Mengklasifikasi meliputi penemuan ciri-ciri atau pola-pola yang relevan, yang cocok dengan contoh spesifik dan konsep atau prinsip.

4. Summarizing (merangkum) terjadi ketika masyarakat mampu mengusulkan pernyataan tunggal yang merepresentasikan penyajian informasi atau rangkuman dari tema umum. Merangkum meliputi konstruksi suatu representasi informasi, membuat suatu rangkuman, seperti menentukan tema atau topik utama.

5. Inferring (menyimpulkan), meliputi penemuan pola dan rangkaian contoh-contoh atau kejadian-kejadian. Menyimpulkan terjadi ketika masyarakat mampu meringkas konsep atau prinsip yang terdiri dari suatu rangkaian contoh-contoh atau kejadian-kejadian melalui pengkodean ciri-ciri yang relevan dari masing-masing kejadian.

6. Comparing (membandingkan) terjadi ketika masyarakat menemukan persamaan dan perbedaan antara dua atau lebih objek atau benda, peristiwa, masalah, atau situasi.

7. Explaining (menjelaskan) terjadi ketika masyarakat mampu membangun dan menggunakan model sebab akibat dari suatu sistem. Model dapat diturunkan dari teori formal, atau bisa didasarkan pada riset atau pengalaman. Penjelasan yang lengkap meliputi mengkonstruksi model sebab akibat, termasuk setiap bagian utama dalam sistem atau setiap peristiwa utama dalam rangkaian, dan menggunakan model untuk menentukan perubahan dalam satu bagian sistem atau hubungan dalam rangkaian yang mempengaruhi perubahan dalam bagian lain.

\section{Motivasi Terhadap Bahaya Karhutla}

Motivasi berasal dari kata motive sebagai suatu perangsang dari dalam, suatu gerak hati dan sebagainya yang meyebabkan seseorang melakukan sesuatu. Motivasi merupakan istilah lebih umum yang menunjuk pada seluruh proses pergerakan, yang berarti membangkitkan motif, membangkitkan daya gerak atau menggerakkan seseorang atau diri sendiri untuk berbuat sesuatu guna mencapai tujuan. Handoko menyatakan suatu motif umumnya terdapat dua unsur pokok yaitu dorongan atau kebutuhan dan tujuan. Terjadi proses interaksi timbal balik antara kedua unsur ini terjadi dalam diri manusia dan dapat dipengaruhi oleh hal-hal lain diluar diri manusia, sehingga dapat terjadi perubahan motivasi dalam waktu relatif singkat bila motivasi yang pertama tidak mungkin terpenuhi (dalam Sobur. A, 2009).

Motivasi adalah keadaan dalam pribadi seseorang yang mendorong keinginan individu untuk melakukan kegiatan tertentu dalam wujud perilaku yang diarahkan pada tujuan untuk mencapai sasaran kepuasan. Perilaku dimulai dengan adanya motivasi atau disebut juga sebagai motif atau kebutuhan. Motivasi ditimbulkan oleh faktor internal yang berasal dari pribadi seseorang dan faktor eksternal yang merupakan kekuatan yang datang dari luar individu yang mendorong untuk melakukan kegiatan. Motivasi merupakan predisposisi yang menyebabkan seseorang berperilaku, termasuk kegiatan organisasi yang berhubungan dengan lingkungan yang masing-masing mempunyai pengaruh berbeda terhadap perilaku (Asnawi S, 2002)

Motivasi merupakan proses psikologis terjadi pada diri manusia, terjadi interaksi antara sikap, kebutuhan, persepsi, proses belajar dan pemecahan persoalan. Motivasi diawali dengan keinginan untuk mempengaruhi perilaku seseorang. Keinginan tersebut melalui proses persepsi yang diterima seseorang. Proses persepsi ini ditentukan oleh kepribadian, sikap, pengalaman, dan harapan seseorang. Selanjutnya apa yang diterima tersebut diberi arti oleh yang bersangkutan menurut minat dan keinginan. Minat ini mendorongnya untuk 
mencari informasi yang digunakan oleh yang bersangkutan mengembangkan beberapa alternatif tindakan dan pemilihan tindakan (Uno H.B, 2011).

\section{Tindakan Pemadaman Kebakaran Hutan dan Lahan (Karhutla)}

Undang-Undang Nomor 24 tahun 2007 tentang Penanggulangan Bencana menyebutkan bahwa bencana kebakaran hutan merupakan salah satu potensi bencana yang disebabkan oleh faktor alam maupun nonalam. Secara eksplisit hal tersebut disebutkan dalam Penjelasan Atas UU No. 24 Tahun 2007 tentang Penanggulangan Bencana yang menjelaskan bahwa potensi penyebab bencana di wilayah Indonesia dapat dikelompokan dalam 3 (tiga) jenis bencana:

1. Bencana alam antara lain berupa gempa bumi karena alam, letusan gunung berapi, angin topan, tanah longsor, kekeringan, kebakaran hutan/lahan karena faktor alam, hama penyakit tanaman, epidemi, wabah, kejadian luar biasa, dan kejadian antariksa/bendabenda angkasa.

2. Bencana nonalam antara lain kebakaran hutan/lahan yang disebabkan oleh manusia, kecelakan transportasi, kegagalan konstruksi/teknologi, dampak industri, ledakan nuklir, pencemaran lingkungan dan kegiatan keantariksaan.

3. Bencana sosial antara lain berupa kerusuhan sosial dan konflik sosial dalam masyarakat yang sering terjadi.

Kebakaran hutan dan lahan adalah suatu kondisi dimana lahan dan hutan dilanda api yang mengakibatkan kerusakan lahan dan hutan atau hasil hutan dan berakibat kerugian secara ekonomis dan atau nilai lingkungan. Dalam kaitan ini terdapat perubahan langsung atau tidak langsung terhadap sifat fisik dan atau hayatinya yang menyebabkan kurang berfungsinya lahan dan hutan dalam mendukung kehidupan yang berkelanjutan. Faktor penyebabnya antara lain karena penggunaan api yang tidak terkendali maupun faktor alam (Nurjanah et al. 2013).

Dilihat dari kelompok faktor penyebab karhutla di Indonesia, faktor alam tampaknya hanya memegang peranan yang sangat kecil, sedangkan faktor manusia menyebabkan hampir $100 \%$ dari kejadian karhutla, baik sengaja maupun tidak sengaja. Namun berbagai studi dan analisis yang dilakukan oleh berbagai pihak yang berkompeten, baik lembaga pemerintahan maupun organisasi-organisasi nasional dan internasional menyimpulkan bahwa hampir 100 persen kebakaran hutan dan lahan di Indonesia disebabkan oleh perbuatan manusia.

Salah satu pendekatan untuk mencegah atau mengurangi dampak yang ditimbulkan akibat suatu bencana adalah melalui pendekatan kultural. Pendekatan ini dilakukan karena masih ada anggapan di kalangan masyarakat bahwa bencana itu adalah takdir sehingga harus diterima apa adanya. Hal ini tidak sepenuhnya benar, karena dengan kemampuan berpikir dan berbuat, manusia dapat berupaya menjauhkan diri dari bencana dan sekaligus mengurangi keparahannya. Oleh karena itu diperlukan pendekatan kultural untuk meningkatkan kesadaran mengenai bencana. Melalui pendekatan kultural, pencegahan bencana disesuaikan dengan kearifan masyarakat lokal yang membudaya sejak lama (Ramli 2010).

Menurut Ginting (2009) upaya-upaya peningkatan pencegahan kebakaran hutan dan lahan dikaitkan dengan partisipasi masyarakat meliputi:

a. Penyuluhan. Melalui penyuluhan ke seluruh lapisan masyarakat diyakinkan bahwa jika terjadi kebakaran hutan dan lahan maka semua pihak akan menderita kerugian. Bukan hanya kerugian materi tetapi bahkan dapat menyebabkan nyawa pun menjadi korban. Selain penyuluhan diberikan juga petunjuk praktis yang mudah dicerna seperti pemasangan tanda gambar, penerangan, papan pengumuman, dan pesan-pesan lainnya. 
b. Pendekatan sosial, ekonomi dan budaya. Manusia merupakan penyebab utama terjadinya kebakaran hutan dan lahan, oleh karena itu diperlukan pendekatan dari berbagai aspek seperti perilaku, budaya, sosial ekonomi dan tingkat pendidikan. Salah satu pendekatan yang dilakukan adalah dengan mengikutsertakan masyarakat sekitar hutan dalam kegiatan kehutanan mulai dari pembuatan persemaian, pembibitan, penanaman, pemeliharaan dan sebagainya.

c. Pembentukan forum dan kelompok pencegahan kebakaran kebakaran hutan di sekitar hutan: (1) forum swadaya, umumnya manusia (masyarakat) yang memiliki komitmen tinggi dan rela berkorban untuk pemeliharaan lingkungan; (2) forum fasilitasi, kerjasama antara masyarakat di sekitar hutan dengan Satuan Tugas Pemadam Kebakaran Hutan dan Lahan.

d. Pengembangan pendekatan lainnya dalam peningkatan peran serta masyarakat, seperti: (1) pemantauan, komunikasi, jaringan informasi dan evaluasi; (2) pendekatan klimatologis; (3) pendekatan teknik sipil; (4) pendekatan silvikultur; (5) pelatihan pengorganisasian.

e. Pemberian insentif dan disinsentif.

\section{Penelitian Terdahulu}

Sabarudi (2009) meneliti pendekatan sosiologis dalam pencegahan kebakaran di DTA Danau Toba dengan penekanan kepada faktor-faktor penyebabnya: a) penggunaan api sebagai alat untuk penyiapan lahan; b) kebakaran yang tidak disengaja; c) kebakaran yang disengaja; d) kebakaran berkaitan dengan usaha perburuan. Hasil penelitian menyebutkan bahwa pendekatan sosiologis dalam pencegahan kebakaran hutan dan lahan dilakukan melalui kegiatan penyuluhan yang lebih menyentuh aspek sosiokulural masyarakat setempat. Sehingga kegiatan pencegahan kebakaran hutan dan lahan dapat lebih terjamin aspek keberlanjutannya di masa mendatang. Salah satu upaya penting dan strategis dalam pendekatan sosiologis dalam pencegahan kebakaran di DTA Danau Toba adalah pembentukan "kepedulian tetangga" di setiap desa untuk menghindari kebakaran hutan yang disebabkan oleh manusia-manusia yang tidak bertanggungjawab.

Prior dan Eriksen (2013)menyajikan hasil penelitian metode campuran (mixedmethods), menggunakan teknik kualitatif dan kuantitatif untuk mengeksplorasi dan melihat faktor-faktor yang mempengaruhi kesiapan rumah tangga yang tinggal di kawasan risiko kebakaran hutan di Australia Tenggara. Hasil penelitian juga menunjukkan bagaimana kohesi sosial, terutama faktor-faktor seperti rasa kebersamaan dan kemampuan anggota masyarakat untuk memecahkan masalah yang mereka hadapi bersama-sama, merupakan komponen kunci kesiapan dan ketahanan menghadapi kebakaran hutan.

Olsen et al. (2014) melakukan penelitian mengenai bencana asap akibat kebakaran hutan dari aspek komunikasi di Amerika Serikat. Peneliti menyajikan temuan-temuan dari studi eksplorasi yang menguji peluang dan tantangan terkait dengan komunikasi (organisasi atau publik) untuk pengelolaan asap dampak kebakaran hutan. Penelitian tersebut membuka wawasan strategi potensial untuk mengatasi bencana asap dengan meningkatkan komunikasi pada antarlembaga, intralembaga, dan anggota masyarakat. Secara khusus, memprioritaskan komunikasi lembaga yang berhubungan dengan kebakaran dan asap, mengalokasikan sumber daya lembaga untuk sosialisasi dan upaya komunikasi, mengambil keuntungan dari sumber daya yang ada termasuk jaringan sosial informal di antara masyarakat, dan membangun hubungan jangka panjang antara pemerintah dengan masyarakat.

Nurdin dan Sukartik (2015) melakukan penelitian model komunikasi pencegahan kebakaran hutan dan lahan berbasis masyarakat dengan kasus kegiatan Masyarakat Peduli Api (MPA) di Desa Sepahat, Kabupaten Bengkalis. Hasilnya menunjukkan bahwa pola dan 
perilaku komunikasi anggota MPA terlaksana dengan baik dan optimal dalam rangka pencegahan Karhutla. Artinya semakin optimal perilaku komunikasi yang dilakukan oleh anggota MPA akan semakin optimal pula komunikasi pencegahan karhutla yang dilakukan oleh anggota MPA. Kemudian penanaman nilai keislaman pada anggota MPA mempunyai peranan yang sangat penting dalam meningkatkan, memantapkan dan mengoptimalkan komunikasi pencegahan karhutla.

Sukartik dan Nurdin (2016) melakukan penelitian tentang pemberdayaan masyarakat dalam pencegahan kebakaran lahan dan hutan melalui desa bebas api (fire free village) di kabupaten pelalawan Provinsi Riau. Hasil kajian menunjukkan bahwa pemberdayaan masyarakat sudah dilakukan terhadap masyarakat di Desa Segati Kecamatan Langgam sudah dilakukan oleh berbagai pihak yang berkepentingan, terutama sekali oleh pemerintah melalui perangkat kecamatan dan desa, akan tetapi belum memberikan hasil yang optimal dalam memberdayakan masyarakat untuk mengambil bagian dalam proses penanggulangan kebakaran hutan di Desa Segati Kecamatan Langgam Kabupaten Pelalawan Riau.

\section{Kerangka Pikir Peneliltian}

Penelitian akan mengungkapkan hubungan beberapa variabel yang saling terkait untuk menjelaskan efektivitas kegiatan sosialisasi yang dilaksanakan oleh berbagai pihak terkait meliputi pihak pemerintah, swasta dan lembaga sosial masyarakat. Hal ini dapat dilihat pada gambar berikut:

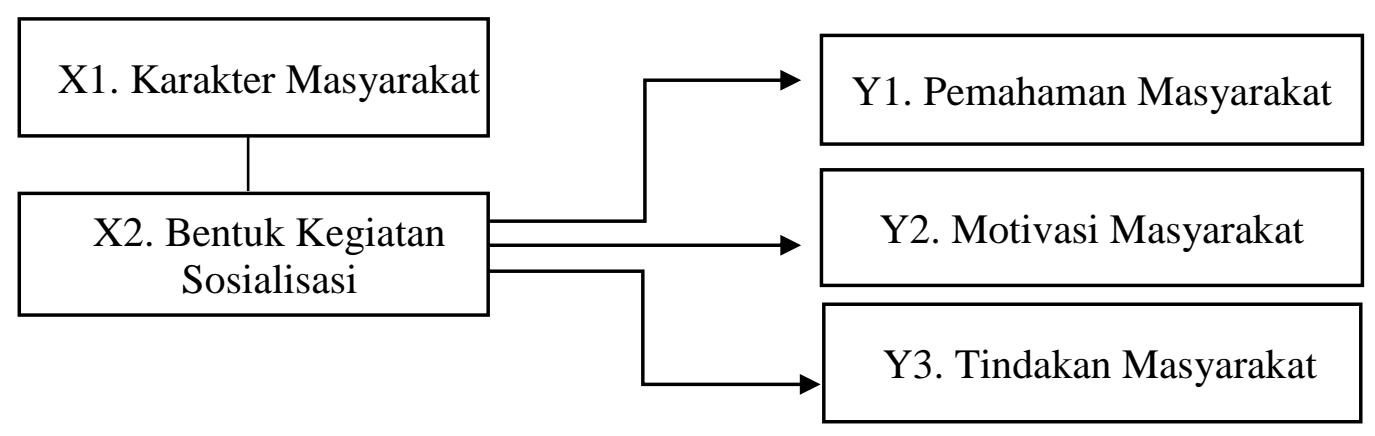

Gambar 1: Kerangka Pikir Penelitian

\section{METODOLOGI PENELITIAN}

Pendekatan yang digunakan dalam penelitian adalah positivisme dan konstruktivisme. Pendekatan positivisme adalah pendekatan yang bertujuan untuk memberikan penilaian terhadap isu-isu yang menjadi permasalahan dalam penelitian. Penelitian ini menggunakan metode survei, yang dilakukan pada populasi besar maupun kecil. Data yang diharapkan adalah data dari sampel yang diambil dari populasi, sehingga ditemukan jawaban-jawaban terhadap permasalahan dalam penelitian, yang mengaitkan kejadian-kejadian relatif, distribusi, dan hubungan-hubungan antar variabel sosiologis maupun psikologis (Sugiyono, 2005). Berdasarkan tingkat explanasi (level of explanation) penelitian ini merupakan penelitian asosiatif (hubungan) yaitu penelitian yang bertujuan untuk mengetahui hubungan antara dua variabel atau lebih (Sugiyono, 2005).

Pendekatan konstruktivisme adalah pendekatan yang menekankan kepada empati, dan interaksi dialektis antara peneliti dan responden untuk merekonstruksi realitas yang diteliti, melalui metode-metode kualitatif yang teknik pengumpulan data meliputi wawancara, Focus Group Discussion (FGD), dan observasi non partisipan terhadap responden kajian (Rahmat K, 2014). 
Populasi kajian ini adalah masyarakat Kecamatan Bunut yang terkena kegiatan sosialisasi yang dilakukan oleh pemerintah, swasta, LSM, dan institusi yang terkait, dengan mengambil sampel pada desa yang terkena program sosialisasi penanggulangan kebakaran hutan dan lahan, yaitu Desa Sungai Buluh Kecamatan Bunut Kabupaten Pelalawan. Teknik pengambilan sampel dengan Purposive Sampling terhadap keluarga petani yang melakukan kegiatan pemadaman Karhutla.

Sebanyak 1.060 Kepala Keluarga petani maka ditelusuri keluarga-keluarga yang terlibat dalam kegiatan pemadaman hutan dan lahan. Diperoleh data dari FGD bahwa 30\% kepala keluarga yang berprofesi sebagai petani terlibat dalam kegiatan pemadaman kebakaran hutan dan lahan dan setelah ditelusuri diperoleh 50 kepala keluarga yang banyak terlibat dengan kegiatan pemadaman kebakaran hutan dan lahan di Desa Sungai Buluh Kecamatan Bunut Kabupaten Pelalawan Provinsi Riau.

Metode pengumpulan data yang digunakan dalam kajian ini adalah metode survey, dengan instrument yang berbentuk angket yang disusun sesuai dengan indikator yaitu karakteristik responden, kagiatan sosialisasi, pemahaman, motivasi dan tindakan masyarakat terhadap pencegahan Karhutla. Focus Group Discussion (FGD), adalah diskusi kelompok juga dilakukan dilakukan di kalangan masyarakat yang menerima proses sosialisasi yang dilakukan oleh stakeholder dan bagian-bagian yang berkepentingan terhadap kebakaran hutan dan lahan. Terutama sekali yang dikembangkan dalam FGD adalah terkait dengan efektivitas sosialisasi yang dijalankan berbagai pihak yang terkait meliputi kegiatan sosialisasi yang dijalankan oleh instansi, pemahaman masyarakat, motivasi masyarakat, dan tindakan masyarakat. Selain itu, dilakukan juga interview mendalam kepada masyarakat terhadap isu sosialisasi bagi pemerintah, swasta dan masyarakat luas, dan observasi non partisipan, terhadap sikap, gaya bahasa, body language responden sewaktu dilaksanakan FGD dan interview.

\section{HASIL PENELITIAN}

\section{Analisis Hubungan Variabel Kajian}

Hubungan diantara variabel dapat digambarkan bahwa hubungan diantara variabel X2: kegiatan sosialisasi dengan variabel Y1: pemahaman masyarakat adalah tinggi pada angka 0,385 , dengan taraf signifikan yang dapat diterima yaitu 0,006. Hal ini memberikan gambaran bahwa kegiatan sosialisasi tentang bahaya kebakaran hutan dan lahan yang dijalankan oleh instansi-instansi terkait memberikan hubungan yang signifikan dengan tingkat pengetahuan masyarakat terhadap bahaya kebakaran hutan dan lahan.

Demikian halnya hubungan antara variabel X2: kegiatan sosialisasi dengan variabel Y3: tindakan masyarakat juga tergolong tinggi pada angka 0,317, dengan taraf signifikan yang dapat diterima yaitu 0,025 . Artinya hubungan ini dapat memberikan gambaran bahwa kegiatan sosialisasi tentang bahaya kebakaran hutan dan lahan yang dijalankan oleh instansiinstansi terkait memberikan hubungan yang signifikan terhadap tindakan masyarakat dalam melakukan kegiatan pemadaman kebakaran hutan dan lahan di Desa Sungai Buluh Kecamatan Bunut.

Hubungan antara variabel X2: kegiatan sosialisasi dengan varibel Y2: motivasi masyarakat adalah tergolong rendah pada angka 0,265 , dengan taraf signifikan yang tidak dapat diterima yaitu 0,062, karena $>0,05$. Artinya hubungan antara dua variabel ini adalah tidak signifikan, kegiatan sosialisasi yang dilaksanakan oleh instansi-instansi terkait tidak berhubungan secara signifikan dengan motivasi masyarakat dalam pelaksanaan pemadaman kebakaran hutan dan lahan. 
Tabel 1: Signifikansi Hubungan Diantara Variabel

\begin{tabular}{|ll|l|l|l|}
\hline & & Pemahaman & motivasi & Tindakan \\
\hline Sosialisasi & Pearson Correlation & $.385^{* *}$ & .265 & $.317^{*}$ \\
& Sig. (2-tailed) & .006 & .062 & .025 \\
& $\mathrm{~N}$ & 50 & 50 & 50 \\
\hline
\end{tabular}

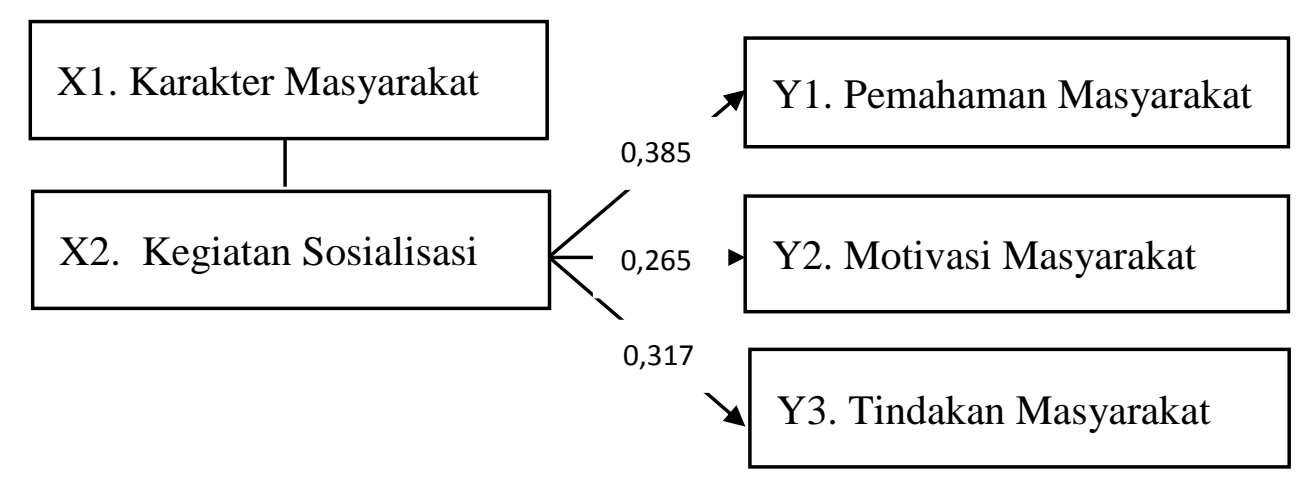

Gambar 2: Hubungan Antara Variabel X dan Variabel Y

Kegiatan sosialisasi mempunyai hubungan dengan motivasi masyarakat dalam mencegah terjadinya Karhutla akan tetapi hubungan tersebut adalah sangat lemah dan hubungan yang terjadi adalah hubungan yang tidak signifikan, karena berada pada nilai signifikan 0,062, yang lebih besar dari taraf signifikansi yang dapat diterima yaitu 0,05.

Kekuatan hubungan diantara variabel X2: kegiatan sosialisasi dengan varibel $\mathrm{Y} 1$ : Pemahaman, Y2: Motivasi, dan Y3: Tindakan, berada pada 15,3\%, jadi variabel X2: Kegiatan sosialisasi hanya memberikan pengaruh sebesar $15,3 \%$ terhadap variabel $\mathrm{Y}$ (pemahaman, motivasi dan tindakan) jadi terdapat faktor-faktor lain yang mempengaruhi variabel Y (sebesar 84,7\%) yang sangat dominan mempengaruhi variabel-variabel Y. Dalam diskusi kelompok (FGD) diperoleh penjelasan bahwa variabel-variabel yang lain yang mempengaruhi adalah media massa, media sosial, komunikasi interpersonal antara warga desa dengan masyarakat luar.

Tabel 2: Model Summary

\begin{tabular}{|l|l|l|l|l|}
\hline Model & R & R Square & Adjusted R Square & Std. Error of the Estimate \\
\hline 1 & $.391^{\mathrm{a}}$ & .153 & .136 & 12.18816 \\
\hline
\end{tabular}

a. Predictors: (Constant), sosialisasi

Pada Tabel Uji Anova atau F test, didapati bahwa 8.680 dengan tingkat signifikansi 0,005 . Oleh karena nilai probabilitas $(0,005)$ jauh lebih kecil dari 0,05 , maka model regresi dapat dipakai untuk memprediksi variabel Y (pengetahuan, motivasi dan tindakan). Artinya sosialisasi yang dilaksanakan dapat memberikan pengaruh yang positif terhadap tingkat pemahaman, motivasi dan tindakan. Artinya peningkatan kegiatan kualitas sosialisasi akan memberikan pengaruh kepada peningkatan kualitas pemahaman, motivasi dan tindakan masyarakat terhadap pencegahan Karhutla. 
Tabel 3: ANOVA $^{\mathrm{b}}$

\begin{tabular}{|ll|ll|l|l|l|l|}
\hline \multicolumn{2}{|l|}{ Model } & $\begin{array}{l}\text { Sum } \\
\text { Squares }\end{array}$ & of & Df & Mean Square & F & Sig. \\
\hline 1 & $\begin{array}{l}\text { Regressio } \\
\mathrm{n}\end{array}$ & 1289.454 & 1 & 1289.454 & 8.680 & $.005^{\mathrm{a}}$ \\
$\begin{array}{l}\text { Residual } \\
\text { Total }\end{array}$ & 7130.466 & 48 & 148.551 & & \\
\hline
\end{tabular}

a. Predictors: (Constant), sosialisasi

b. Dependent Variable: pemahaman + motivasi + tindakan

Tabel 4: Coefficients ${ }^{\mathrm{a}}$

\begin{tabular}{|c|c|c|c|c|c|c|}
\hline & \multirow[t]{2}{*}{ Model } & \multicolumn{2}{|c|}{$\begin{array}{c}\text { Unstandardized } \\
\text { Coefficients }\end{array}$} & \multirow{2}{*}{\begin{tabular}{|l}
$\begin{array}{l}\text { Standardized } \\
\text { Coefficients }\end{array}$ \\
Beta \\
\end{tabular}} & \multirow[b]{2}{*}{$\mathrm{t}$} & \multirow[b]{2}{*}{ Sig. } \\
\hline & & B & Std. Error & & & \\
\hline \multirow[t]{2}{*}{1} & (Constant) & 99.055 & 5.991 & & 16.534 & .000 \\
\hline & sosialisasi & .739 & .251 & .391 & 2.946 & .005 \\
\hline
\end{tabular}

a. Dependent Variable: pemahaman + motivasi + tindakan

Nilai signifikan adalah 0,000 yang menandakan bahwa probabilitas jauh dibawah 0,05 maka koefisien regresi adalah signifikan, atau variabel sosialisasi berpengaruh secara signifikan terhadap variabel dependen yaitu pengetahuan, motivasi dan tindakan. Meskipun disadari bahwa kekuatan hubungan variabel X2: sosialisasi dengan variabel Y (pemahaman, motivasi dan tindakan) hanya 0,391 . Akan tetapi hubungan itu berada pada nilai signifikansi yang dapat diterima yaitu 0,005 .

Secara umum variabel independen "kegiatan sosialisasi" memberi pengaruh kepada variabel dependen "pemahaman, motivasi dan tindakan" terhadap kebakaran hutan dan lahan, akan tetapi disadari bahwa kegiatan sosialisasi yang dijalankan oleh instansi berwajib adalah masih sangat terbatas. Hal ini terjadi karena kegiatan sosialisasi kebanyakan dilaksanakan dengan sistem perwakilan desa dalam berbagai kegiatan sosialisasi, di provinsi, kabupaten dan kecamatan, dan penyampaian hasil sosialisasi oleh utusan desa kepada masyarakat adalah tidak optimal dijalankan, sehingga pemahaman masyarakat terhadap Karhutla adalah sangat terbatas. Informasi yang sampai kepada masyarakat hanya bersifat ancaman dan hukuman yang menakutkan.

Pada kegiatan FGD, tergambar bahwa akibat larangan membakar lahan dan hutan di Desa Sungai Buluh Kelurahan Bunut Kecamatan Bunut, berakibat kepada hilangnya kearifan lokal masyarakat, yang mungkin selama ini tidak terpikirkan oleh pemerintah. Yaitu: 1) Kebiasaan masyarakat membuka lahan dengan cara membakar tidak ada lagi. 2) Hilangnya kebiasaan basolang, budaya masyarakat setempat membuka lahan dengan cara membakar lahan dengan cara gotong royong, dimana kebiasaan masyarakat ketika membakar lahan sebelum api mati belum pulang. Kondisi yang dilakukan selama ini cukup aman. Sebab wilayah lahan yanag akan dibakar juga melibatkan pemilik lahan yang bersepadan. Selain itu lahan yang ada juga dibatasi dengan parit sedalam dua meter sekeliling tanah masyarakat. Kearifan lokal ini mulai hilang 3-4 tahun terakhir sejak bencana asap akibat kebakaran hutan 
dan lahan. 3) Kebiasaan masyarakat menanam padi tidak ada lagi karena biasanya menggunakan pupuk dari hasil pembakaran karena tingkat kesuburan tanaman sangat baik. Akibatnya beras pun sudah dibeli. Begitu juga dengan tanaman kecil tidak ada lagi. Kebiasaan menanam cabe, menanam sayur juga tidak ada lagi. 4) Berangsur-angsur menghakis rasa kekeluargaan masyarakat Desa Sungai Buluh.

Sehingga menimbulkan masalah yang terjadi dalam masyarakat adalah: 1) petumbuhan ekonomi masyarakat terhambat karena tidak bisa membuka lahan karena takut masuk penjara, 2) masyarakat tak sanggup mengelola lahan karena tingginya biaya, akhirnya menjual tanahnya kepada orang lain, 3) yang terjadi adalah "yang kaya semakin kaya dan yang miskin tambah miskin", 4) masyarakat menerima keputusan pemerintah secara paksa dan penuh tekanan, 5) bukan kesadaran masyarakat yang muncul dari larangan yang disampaikan pemerintah dan perusahaana tapi rasa ketakutan kepada hukuman "dipenjara" yang menjadi momok bagi masyarakat ketika melakukan pembakaran lahan.

Solusi yang ditawarkan pihak perusahaan bagi masyarakat yang ingin membuka lahan adalah dengan meminjamkan alat berat saja. Kerjasama dengan perusahaan hanya sebatas dalam bentuk peralatan pencegahan Karhutla. Peminjaman hanya pada saat dibutuhkan tapi peminjaman terbatas pada satu desa 20 hektar, sehingga solusi yang dapat mensejahterakan masyarakat belum terwujud. Pemerintah desa terkesan menerima keputusan larangan membakar lahan bagi masyarakat, tanpa ada solusi yang dapat meringankan beban ekonomi masyarakat.

\section{DISKUSI DAN PEMBAHASAN}

Kegiatan sosialisasi kepada masyarakat sudah dijalankan, akan tetapi keterlibatan masyarakat pada kegiatan sosialisasi yang sangat terbatas, karena kegiatan sosialisasi hanya diwakili perangkat desa pada level-level kecamatan, kabupaten dan provinsi. Setelah pelaksanaan sosialisasi di tingkat kecamatan, kabupaten dan provinsi, baru kemudian warga mendapat sosialisasi yang dilaksanakan oleh utusan yang mendapat kepercayaan untuk mewakili pemerintah desa. Ini artinya kegiatan sosialisasi belum memberikan pengaruh yang lebih baik untuk melakukan tindakan pencegahan Karhutla.

\section{Kegiatan Sosialisasi Pencegahan Karhutla}

Kegiatan sosialisasi sangat erat kaitannya dengan disiplin ilmu komunikasi. Dimana komunikasi adalah merupakan gambaran seseorang tentang stimulasi dalam pikiran orang lain atas kesadaran, pemahaman, dan perasaan akan pentingnya peristiwa, perasaan, fakta, opini, atau situasi, selain itu komunikasi diantara manusia adalah seni mentransmisi informasi, ide, dan sikap dari satu orang ke orang yang lain (Santoso, 2010).

Kegiatan sosialisasi untuk memberikan pemahaman kepada masyarakat tentang bahaya Karhutla di Desa Sungai Buluh sudah dilaksanakan oleh berbagai instansi terkait. Meskipun disadari masyarakat bahwa mereka belum menerima sosialisasi dengan baik dan sempurna, sehingga tergambar bahwa kegiatan sosialisasi belum dirasakan pengaruhnya di kalangan masyarakat Desa Sungai Buluh. Hal ini terjadi karena kegiatan sosialisasi kebanyakannya dilaksanakan di ibu kota provinsi, ibu kota kabupaten, dan kecamatan, dan aparat desa hanya diundang untuk menjadi peserta kegiatan sosialisasi Karhutla, yang diharapkan aparat desa yang menjadi utusan dari Desa Sungai Buluh dapat menyampaikan kepada masyarakat desa. Akan tetapi kegiatan sosialisasi yang dilaksanakan oleh aparat desa kepada warga adalah tidak optimal sesuai pengakuan masyarakat.

Sebagaimana digambarkan di atas bahwa sebagian besar masyarakat tidak menyadari dan tidak mengerti terhadap kegiatan sosialisasi yang dilaksanakan oleh pihak-pihak yang berkepentingan, artinya sosialisasi tidak sampai kepada masyarakat. Hal ini dapat dimaklumi 
karena pesan sosialisasi hanya dititipkan pada petugas desa yang juga tidak mempunyai pengetahuan yang cukup, dan perhatian yang tidak fokus tapi hanya sekedar memenuhi undangan dari pihak-pihak terkait.

Demikian halnya dalam proses penyampaian hasil sosialisasi oleh aparat desa hanya bersifat seadanya, misalnya disampaikan saat rapat desa, saat ada acara pertemuan, bahkan kadang-kala pesan sosialisasi disampaikan saat acara kenduri atau perkawinan. Hal ini terjadi karena terbatasnya kemampuan pendanaan, kemampuan penguasaan materi sosialisasi, sehingga penerimaan masyarakat juga sangat terbatas.

\section{Pemahaman Masyarakat Terhadap Pencegahan Karhutla}

Suharsimi Arikunto (1995) menyatakan bahwa pemahaman (comprehension) adalah kemampuan seorang mempertahankan, membedakan, menduga (estimates), menerangkan, memperluas, menyimpulkan, menggeneralisasikan, memberikan contoh, menuliskan kembali, dan memperkirakan. Dengan demikian dapat dimaknai bahwa pemahaman adalah suatu kemampuan seseorang dalam mengartikan, menafsirkan, menerjemahkan, atau menyatakan sesuatu dengan caranya sendiri tentang pengetahuan yang pernah diterimanya.

Pemahaman masyarakat terhadap bahaya Karhutla tergolong baik karena terdapat $77 \%$ responden menyatakan "paham dan sangat paham" terhadap bahaya dan akibat dari Karhutla yang terjadi di Desa Sungai Buluh. Meskipun kegiatan sosialisasi tidak optimal tetapi pemahaman masyarakat adalah sangat baik, dengan demikian terdapat sumber-sumber informasi yang lain, selain dari kegiatan sosialisasi. Seperti, media massa, media sosial dan melalui komunikasi interpersonal antara warga masyarakat. Namun demikian hubungan kegiatan sosialisasi dengan pengetahuan masyarakat adalah signifikan artinya kegiatan sosialisasi memberikan pengaruh terhadap pemahaman masyarakat. Hubungan yang signifikan memberikan indikasi bahwa mengoptimalkan kegiatan sosialisasi adalah sangat penting untuk meningkatkan dan meluruskan pemahaman masyarakat terhadap bahaya Karhutla.

Kegiatan FGD memberikan gambaran bahwa masyarakat memahami bahaya Karhutla baru pada dataran pemahaman yang sangat terbatas dan memerlukan pemahaman yang komprehensip terhadap bahaya Karhutla, sehingga mereka tetap dapat meningkatkan tarap penghidupan yang layak bagi mereka. Berdasarkan pemaparan Suharsimi Arikunto di atas tergambar bahwa pemahaman masyarakat adalah belum optimal, oleh karena itu kegiatan sosialisasi harus diupayakan secara baik dan terencana, sehingga pemahaman dapat terwujud dengan baik dan komprehensip.

\section{Motivasi Masyarakat Terhadap Pencegahan Karhutla}

Motivasi adalah keadaan dalam pribadi seseorang yang mendorong keinginan individu untuk melakukan kegiatan tertentu dalam wujud perilaku yang diarahkan pada tujuan untuk mencapai sasaran kepuasan. Perilaku dimulai dengan adanya motivasi atau disebut juga sebagai motif atau kebutuhan. Motivasi ditimbulkan oleh faktor internal yang berasal dari pribadi seseorang dan faktor eksternal yang merupakan kekuatan yang datang dari luar individu yang mendorong untuk melakukan kegiatan. Motivasi merupakan predisposisi yang menyebabkan seseorang berperilaku, termasuk kegiatan organisasi yang berhubungan dengan lingkungan yang masing-masing mempunyai pengaruh berbeda terhadap perilaku (Asnawi S, 2002).

Motivasi masyarakat terhadap kegiatan pencegahan Karhutla adalah sangat baik terdapat $78 \%$ responden "setuju dan sangat setuju" artinya masyarakat sangat termotivasi dengan kegiatan pencegahan Karhutla dan terdapat hanya $10 \%$ responden yang menyatakan "tidak setuju" terhadap kegiatan sosialisasi terhadap bahaya Karhutla. Meskipun demikian 
kegiatan sosialisasi tidak mempunyai korelasi yang signifikan dengan motivasi masyarakat, artinya kegiatan sosialisasi tidak memberikan pengaruh yang signifikan terhadap motivasi masyarakat dalam kegiatan pencegahan Karhutla.

Jadi motivasi masyarakat terhadap pencegahan Karhutla yang baik tidak dipengaruhi oleh kegiatan sosialisasi akan tetapi dipengaruhi oleh faktor-faktor lain, seperti media massa, media sosial, komunikasi interpersonal dan lain-lain. Motivasi masyarakat terhadap Karhutla baru pada tataran untuk menghindari ancaman, sebaiknya kegiatan sosialisasi diharapkan memperbaiki motivasi masyarakat terhadap pencegahan Karhutla.

Motivasi yang merupakan predisposisi yang menyebabkan seseorang berperilaku, termasuk kegiatan organisasi yang berhubungan dengan lingkungan yang mempunyai pengaruh berbeda terhadap perilaku belum terwujud bagi masyarakat Desa Sungai Buluh, karena kesadaran terhadap kegiatan pencegahan Karhutla lebih didasarkan pada rasa takut terhadap ancaman hukuman.

\section{Tindakan Masyarakat Terhadap Pencegahan Karhutla}

Tindakan masyarakat terhadap aktivitas pencegahan Karhutla terlihat jelas bahwa masyarakat mempunyai keterlibatan yang tinggi dalam aktivitas pencegahan Karhutla, terdapat $73 \%$ responden yang menyatakan "sering" dan "sangat sering" dengan tindakantindakan pencegahan karhutla, dan hanya $11 \%$ responden yang menyatakan "tidak pernah". Artinya tindakan masyarakat terhadap kegiatan Karhutla adalah sangat baik, dan kegiatan sosialisasi mempunyai hubungan yang signifikan terhadap tindakan masyarakat dalam melakukan pencegahan karhutla. Meskipun disadari bahwa pengaruh sosialisasi terhadap tindakan masyarakat adalah rendah, sehingga dapat dipahami bahwa tindakan yang baik bagi masyarakat dipengaruhi oleh faktor-faktor lain, seperti media massa, media sosial, sekolah, dan komunikasi interpersonal.

Tindakan penanggulangan bencana sebagaimana yang dijelaskan dalam UU No. 24 Tahun 2007, bahwa potensi penyebab bencana di wilayah Indonesia dapat dikelompokan dalam tiga jenis bencana yaitu: 1) Bencana alam antara lain berupa gempa bumi karena alam, letusan gunung berapi, angin topan, tanah longsor, kekeringan, kebakaran hutan/lahan karena faktor alam, hama penyakit tanaman, epidemi, wabah, kejadian luar biasa, dan kejadian antariksa/benda-benda angkasa. 2) Bencana non-alam antara lain kebakaran hutan/lahan yang disebabkan oleh manusia, kecelakan transportasi, kegagalan konstruksi/teknologi, dampak industri, ledakan nuklir, pencemaran lingkungan dan kegiatan keantariksaan. Dan 3) Bencana sosial antara lain berupa kerusuhan sosial dan konflik sosial dalam masyarakat yang sering terjadi.

Ketiga bentuk bencana yang digambarkan diatas terjadi di Desa Sungai Buluh, yaitu bencana alam, non alam dan bencana sosial. Oleh karena itu tindakan pencegahan kebakaran yang dilaksanakan oleh masyarakat memerlukan pemahaman yang jelas, sehingga tidak semua tindakan kebakaran hutan dan lahan dapat dikategorikan sebagai bencana alam, dan tentunya tingkat penegakan hukum juga akan berbeda satu dengan yang lainnya.

\section{Efektivitas Kegiatan Sosialisasi Bagi Warga Masyarakat Desa Sungai Buluh Kecamatan Bunut Kabupaten Pelalawan}

Kegiatan sosialisasi yang dilaksanakan oleh berbagai instansi pemerintah meliputi Pemerintah Pusat, Daerah, dan Tingkat Kecamatan, BPBD, dan Lembaga Swasta meliputi Perusahaan, LSM, Manggala Agni, dan lainnya sudah berjalan sesuai dengan harapan pelaksana sosialisasi. Akan tetapi kegiatan tersebut belum sepenuhnya dirasakan oleh masyarakat. Hal ini tergambar bahwa hubungan kegiatan sosialisasi berkorelasi signifikan dengan pengetahuan dan tindakan pencegahan Karhutla dan hubungan yang tidak signifikan 
dengan motivasi masyarakat dalam melakukan pencegahan Karhutla. Sehingga dapat dimaknai bahwa kegiatan sosialisasi yang dilakukan oleh instansi pemerintah dan swasta hendaknya mendapat perhatian yang serius dan dilaksanakan dengan strategi dan perencanaan yang baik dan sistematis, sehingga pesan-pesan yang disampaikan dapat diterima dengan baik oleh masyarakat.

Masyarakat melaksanakan kegiatan yang disosialisasikan dengan penuh pemahaman, kesadaran, motivasi dan sikap tepat, sehingga tidak mendatangkan kerugian dan pengaruh yang negatif bagi masyarakat, seperti sikap pesimis, apriori dan pasrah dengan keadaan dan kemiskinan. Hal yang demikian adalah tidak sesuai dengan tujuan pembangunan nasional yaitu menggerakkan dan memberdayakan masyarakat dalam melakukan pembangunan.

Sosialisasi dianggap efektif apabila memenuhi beberapa persyaratan sebagaimana digambarkan oleh Rumanti (2005) yaitu masyarakat mempunyai (1) kemampuan mengamati dan menganalisis persoalan; (ii) kemampuan menarik perhatian; (iii) kemampuan mempengaruhi pendapat; dan (iv) kemampuan menjalin hubungan dan suasana saling mempercayai. Kegiatan sosialisasi bagi masyarakat Desa Sungai Buluh adalah belum efektif karena masih terdapatnya simpang siur pemahaman bagi masyarakat.

\section{PENUTUP}

Kegiatan sosialisasi belum terlaksana dengan baik dan optimal hal ini tergambar bahwa terdapat 58\% responden menyatakan bahwa mereka "tidak pernah" mendapatkan kegiatan sosialisasi yang dilakukan oleh institusi dan lembaga yang terkait dengan kegiatan sosialisasi pencegahan Karhutla di Desa Sungai Buluh, dan hanya 10\% responden yang menyatakan "sangat sering" mendapatkan kegiatan sosialisasi.

Tingkat pemahaman masyarakat terhadap bahaya Karhutla adalah tergolong cukup baik karena terdapat 49\% responden menyatakan "paham" terhadap bahaya Karhutla yang terjadi di Desa Sungai Buluh, dan terdapat 28\% responden yang menyatakan "sangat paham" terhadap bahaya Karhutla yang terjadi dan hanya $15 \%$ responden yang menyatakan tidak paham dengan informasi terkait bahaya Karhutla. Sementara itu, motivasi masyarakat terhadap penanggulangan Karhutla adalah tergolong tinggi hal ini tergambar dari pengakuan responden terdapat rata-rata $57 \%$ responden "setuju" terhadap pernyataan yang dikemukakan kepada responden, dan rata-rata $21 \%$ yang menyatakan "sangat setuju", dan terdapat ratarata $10 \%$ yang "tidak setuju” dengan pernyataan yang dikemukakan kepada responden.

Terkait dengan tindakan masyarakat terhadap aktivitas pencegahan Karhutla dapat dijelaskan bahwa masyarakat mempunyai keterlibatan yang tinggi dalam aktivitas pencegahan Karhutla, terdapat $51 \%$ responden menjawab"sering" dan $22 \%$ responden yang menjawab "sangat sering" dengan tindakan-tindakan pencegahan Karhutla, dan hanya 11\% responden yang menjawab "tidak pernah". Kegiatan sosialisasi mempunyai hubungan yang signifikan dengan pengetahuan dan tindakan masyarakat terhadap pencegahan Karhutla dan hubungan kegiatan sosialisasi dengan motivasi masyarakat dalam mencegah terjadinya Karhutla adalah sangat lemah dan tidak signifikan, karena berada pada nilai signifikan 0,062, yang lebih besar dari taraf signifikansi yang dapat diterima yaitu 0,05 .

Kekuatan hubungan diantara variabel kegiatan sosialisasi dengan varibel pemahaman masyarakat, motivasi masyarakat dan tindakan masyarakat, adalah 15,3\%, jadi variabel kegiatan sosialisasi memberikan pengaruh hanya sebesar $15,3 \%$ terhadap variabel pemahaman, motivasi dan tindakan masyarakat jadi terdapat faktor-faktor lain yang lebih berpengaruh yaitu sebesar $84,7 \%$. Media massa, media sosial dan komunikasi interpersonal masyarakat dengan masyarakat sekitar Desa Sungai Buluh Kecamatan Bunut sangat dominan mempengaruhi pemahaman, motivasi dan tindakan masyarakat. Hal ini terungkap 
pada saat FGD, sehingga dapat dijelaskan kegiatan sosialisasi tentang bahaya Karhutla di Desa Sungai Buluh Kecamatan Bunut adalah belum efektif.

Kegiatan sosialisasi harus lebih optimal dijalankan oleh pemerintah dengan melibatkan seluruh lapisan masyarakat, tidak melalui perwakilan aparatur desa, yang tidak optimal untuk menyampaikan hasil sosialisasi dengan baik dan komprehensip. Kegiatan sosialisasi yang dilakukan hendaknya tidak berorientasi pada proyek dan anggaran, akan tetapi hendaknya berorientasi pada hasil dan pencapaian, berupa pemahaman, motivasi dan tindakan yang baik bagi masyarakat. Pemerintah hendaknya melakukan kegiatan yang terukur dan berlandaskan kepada riset ilmiah, sehingga kegiatan sosialisasi dapat optimal sampai pada lapisan masyarakat yang menjadi objek dan sasaran program kegiatan tersebut. Sosialisasi hendaknya dijalankan secara komprehensip, sehingga masyarakat tetap optimis dalam menata masa depan mereka, tanpa menghilangkan kearifan lokal yang masih bernilai positif bagi kehidupan masyarakat ke depan.

\section{REFERENSI}

Anderson, L., \& Krathwohl, D. A. 2001. Taxonomy for Learning, Teaching and Assessing: A Revision of Bloom's Taxonomy of Educational. Alamat: www.apsna.org/resource/resmgr/2014/apsna_guidelineshowcompletef.

Arikunto, Suharsimi. 1995. Dasar-dasar Evaluasi Pendidikan. Bumi. Aksara, Jogjakarta.

Arredondo, Lani. 2007. Communicate Effectiveley. McGrawHill, New York.

Arni Muhammad. 2005. Komunikasi Organisasi. Bumi Aksara, Jakarta.

Asnawi, S. 2002. Teori Motivasi Dalam Pendekatan Psikologi Industri Dan Organisasi. Studia Press, Jakarta.

Badan Pusat Statisti (BPS) Pelalawan. 2017. Kecamatan Bunut Dalam Angka 2017. Badan Pusat Statistik (BPS) Kabupaten Pelalawan http://prodeskel.binapemdes. kemendagri.go.id/mpublik/

Beebe SA, Beebe SJ, Ivy DK. 2011. Communication: Principles for A Lifetime. Fourth Edition. Allyn \& Bacon, Boston (US).

Fiske J. 2012. Pengantar Ilmu Komunikasi. Rajawali Pers, Yogyakarta.

Ginting T. 2009. Pencegahan Kebakaran Hutan dan Lahan Melalui Partisipasi Masyarakat. Dalam Prosiding Workshop Teknik Pencegahan Kebakaran Hutan Melalui Partisipasi Masyarakat. Kabanjahe (ID): Puslitbang Hutan dan Konservasi Alam dan Dinas Kehutanan Kabupaten Karo.

Liebes, T. (1992). Television, parent, and political socialization of children. Teacher Collage Record, 30(1): 73 - 86 .

Mulyana D. 2009. Ilmu Komunikasi: Suatu Pengantar. Remaja Rosdakarya, Bandung.

Nurdin, Sukartik. 2015. Model Komunikasi Pencegahan Kebakaran Hutan dan Lahan Berbasis Masyarakat Di Kabupaten Bengkalis. Laporan Hasil Penelitian LPPM UIN Suska Riau.

Nurjanah, Sugiharto R, Kuswanda D, Siswanto, Adikoesoemo. 2013. Manajemen Bencana. Alvabeta, Jakarta.

Pearson JC, Nelson PE, Titswort S, Harter L. 2011. Human Communication.Fourth Edition. McGraw-Hill, New York (US).

Poerwadarminta, W. J. S. 2003. Kamus umum Bahasa Indonesia. Balai Pustaka, Jakarta.

PPE Sumatera. 2014. Laporan Pelaksanaan Penanggulangan Bencana Asap 26 Februari - 4 April 2014.PPE Sumatera, Pekanbaru.

Prior T, Eriksen C. 2013. Wildfire preparedness, community cohesion and social-ecological systems. Global Environmental Change, Volume 23, Issue 6, December 2013, Pages 
1575-1586. Tersedia di: http://www.sciencedirect.com/science/article/pii/ S0959378013001684[Diunduh 2 November 2014].

Rahmat Kriyantono . 2014. Teknik Praktis Riset Komunikasi. Kencana, Jakarta.

Ramli S. 2010. Pedoman Praktis Manajemen Bencana (Disaster Management). Dian Rakyat, Jakarta.

Rumanti, Sr. Maria Assumpta.2005. Dasar-Dasar Public Relations Teori dan Praktik. PT Grasindo, Jakarta.

Sahat M.P., dan Supena F, 2007. Memahami Penyebab Kebakaran Hutan Dan Lahan Serta Upaya Penanggulangannya: Kasus Di Provinsi Kalimantan Barat. Alamat:portalgaruda.org/article.php?article=13053\&val=926, diakses 24 Maret 2017

Sabarudi. 2009. Pencegahan Kebakaran Hutan di Sekitar Wilayah Danau Toba: Sebuah Pendekatan Sosiologis. Dalam Prosiding Workshop Teknik Pencegahan Kebakaran Hutan Melalui Partisipasi Masyarakat. Kabanjahe (ID): Puslitbang Hutan dan Konservasi Alam dan Dinas Kehutanan Kabupaten Karo.

Sugiyono,2005. Metode Penelitian Bisnis. Alfabeta, Bandung.

Sobur, A. 2009. Psikologi Umum. Cetakan Ke-2, Pustaka Setia, Bandung

Santoso, edi dan Setiansah, Mite. 2010. Teori Komunikasi. Graha Ilmu, Yogyakarta.

Sphere P. 2006. Piagam Kemanusiaan dan Standar Minimum dalam Respons Bencana. Grasindo, Jakarta.

Sukartik dan Nurdin. 2016. pemberdayaan masyarakat dalam pencegahan kebakaran lahan dan hutan melalui desa bebas api (fire free village) di kabupaten pelalawan Provinsi Riau. Laporan Hasil Penelitian LPPM UIN Suska Riau.

Tempo. 2014, 13 Desember. Jumlah Titik Api di Riau Naik Drastis 2014. [diunduh 2015 3Jan] Tersedia pada: http://www.tempo.co/read/news/2014/12/13/206628222/ Jumlah-Titik-Api-di-Riau-Naik-Drastis-2014

Uno H.B. 2011. Teori Motivasi Dan Pengukurannya, Analisis Di Bidang Pendidikan. Cet Ke-7, Bumi Aksara, Jakarta. 